\title{
The Use of Mediation to Resolve Dispute on Health Services as a Legal Protection for Nurse
}

\author{
Yulianti Wulandari ${ }^{1}$, Faisal Satiago ${ }^{2}$ \\ Doctoral of Law Program, Universitas Borobudur Jakarta \\ \{wulanunborr@gmail.com¹, faisalsantiago@borobudur.ac.id²\}
}

\begin{abstract}
Health is a basic need of every human being and is a human right that is recognized constitutionally in the 1945 Constitution of the Republic of Indonesia. This human right in the health sector is realized through health development which is realized through the provision of health services supported by health resources, such as nurses. Nurses as health workers in carrying out their duties and professions often face disputes caused by community/patient dissatisfaction with the health services provided which leads to the realm of law. For that, we need an alternative dispute resolution to be able to resolve it. One such alternative is to use mediation to resolve disputes in health services that occur. Legal protection for nurses is crucial because a nurse has ethical obligations and professional obligations in carrying out her duties and profession. Legal provisions for the protection of nurses as health workers are contained in Law Number 36 of 2009 concerning Health, Law Number 36 of 2014 concerning Health Workers, and Law Number 38 of 2014 concerning Nursing. This study aims to determine the use of mediation to resolve disputes in health services as legal protection for nurses. This research is normative legal research. The approach used in this research is a statutory approach and a conceptual approach.
\end{abstract}

Keywords: Mediation; Dispute; Legal Protection

\section{Introduction}

Health as a human right that is constitutionally recognized in the 1945 Constitution of the Republic of Indonesia is a citizen's right and state responsibility. This human right in the health sector must be realized through health development aimed at improving the welfare of individuals, families, and communities by instilling healthy living habits. The implementation of health development is realized through the provision of health services supported by health resources, both health workers and non-health workers. Nurses in carrying out health services act as administrators of nursing practice, providers of nursing care, counselors and counselors for clients, managers of nursing services, and nursing researchers. Nursing services provided by nurses are based on knowledge and competence in the field of nursing science developed according to client needs, scientific developments, and the demands of globalization. 
These health services include nursing services that are carried out responsibly, accountably, with quality, and safely by nurses who have obtained registration and permission to practice. Philosophically, nurses have contributed greatly to improving health status. Nurses play a role in providing health services ranging from government and private services, from urban areas to remote villages and border areas. However, this service in reality has not been matched by the provision of legal protection tends to become a legal object. The phenomenon that occurs is rampant legal guidance on the practice of health workers, including nursing, is often identified with the failure of health care efforts. Therefore, nurses in carrying out health services who act as administrators of nursing practice have the right to obtain legal protection in carrying out their duties and profession.

Legal protection for nurses in Indonesia is broadly regulated in Law Number 36 of 2009 concerning Health, which states that "health workers are entitled to compensation and legal protection in carrying out their duties according to their profession" [1]. Then Law Number 36 of 2014 concerning Health Workers, which states that "In carrying out their practice, Health Workers have the right to legal protection under the provisions of laws and regulations" [2]. Furthermore, Law Number 38 of 2014 concerning Nursing, which reads "in carrying out nursing practice, nurses have the right to obtain legal protection as long as they carry out their duties following service standards, professional standards, standard operating procedures, and provisions of laws and regulations" [3].

The importance of legal protection for nurses is because there are often disputes in health services or medical disputes that lead to the realm of law by filing lawsuits by the community or patients to nurses. Society or patients often identify with medical negligence, even though what happened was not medical negligence in health services. It is known that the cause of disputes in health services between nurses and patients is if the patient is dissatisfied with nurses in providing health services. This dissatisfaction in providing health services or due to an alleged mistake or negligence of nurses in carrying out their duties so is considered to cause harm to the patient. For the losses experienced, most of what happened were that the patient made a complaint to the legal apparatus and thought it was the nurse's fault in providing health services that must be prosecuted both civil and criminal.

Another reason is when the nurse has carried out all procedures and works according to standards but the results are not as expected in the healing process, even the patient suffers from disabilities or even dies because of the principle of res ipsa loquitur [4] it will still be legally processed if there is a patient report or patient's family. To law enforcement agencies, there is a generalization that every adverse event (unexpected events) is malpractice of nurses. Many factors cause this unexpected incident, such as the absence of expert health personnel when needed, the lack of supporting facilities and infrastructure for health services, and so on.

As it is known that disputes in health services that are not caused by "deliberate" are civil disputes, however, the public or patients often as well as law enforcement officials often bring their demands to the criminal realm. Based on the prevailing laws and regulations, civil dispute resolution, such as disputes in health services or medical disputes in addition to being proposed to the general court, is also open to the possibility of being submitted through arbitration and alternative dispute resolution. Alternative dispute resolution is a dispute resolution institution or difference of opinion through procedures agreed by the parties, namely settlement outside the court through consultation, negotiation, mediation, conciliation, or expert judgment. One alternative dispute resolution is to use mediation.

It is through this mediation that disputes in health services are resolved through negotiations involving a neutral third party (mediator), and whose presence is expected to be accepted by the patient and nurse. Decision-making is not in the hands of the mediator but the 
hands of the disputing parties. Under Law No. 30 of 1999 concerning Arbitration and Alternative Dispute Resolution which states that "civil disputes or differences of opinion can be resolved by the parties through alternative dispute resolution based on good faith by overriding litigation settlement in the District Court" [5].

Alternative dispute resolution using mediation in resolving disputes in health services is intended so that not all health service disputes are not transferred directly to law enforcement agencies or courts as long as they can be resolved by mediation. Because of the settlement of disputes to court in addition to taking a long time, the parties also incur a lot of costs. Besides, the name of the nurse as a health worker and the institution where they work is not damaged because it is not necessarily a civil or criminal act in health services.

The problem of disputes in health services is what makes it very interesting to research more focused and deeply from the perspective of legal science in the form of the use of mediation in health service disputes as legal protection for nurses. Assessing how the legal protection of nurse health workers based on the perspective of Law no. 36 of 2009 concerning Health, Law no. 36 of 2014 concerning Health Workers, and Law no. 38 of 2014 concerning Nursing.

\section{Research Problem}

According to the background above, then the research problem can be formulated as below: How is the use of mediation to resolve dispute on health service as legal protection for nurse?

\section{Literature Review}

\subsection{Concept of Dispute}

Disputes are problems that can and can occur to every human being, anyone and anywhere. Disputes can occur between individuals and individuals, between individuals and groups, between groups and groups, between citizens and the government, between countries and other countries, between producers and consumers, and so on.

In the English vocabulary, there are 2 (two) terms, namely "conflict" and "dispute", both of which contain the meaning of the difference in interests between the two or more parties, but they can be distinguished. A conflict is a situation in which two or more parties are met with different interests, but it cannot develop into a dispute if the party who feels aggrieved only keeps a feeling of dissatisfaction in his heart. A conflict develops or turns into a dispute when the party who feels aggrieved has expressed dissatisfaction, either directly to the party deemed to be disturbing or to another party. This means that the dispute is a continuation of the conflict that cannot be resolved [6].

The word dispute (conflict; dispute) should not only be destructive and harmful; but rather constructive, interesting/challenging, and dynamic as a catalyst for change [7]. Meanwhile, the definition of a dispute is a condition caused by two or more people characterized by several overt contradictions, the sign can be divided into 2 types of conflict, namely conflict of interest and claims of right. A conflict of interest occurs when two people have the same desire for an object that is considered valuable, while claims of right are claims of truth on the one hand and consider the other party guilty [8]. 
Dean G Pruit stated that disputes are perceived divergence of interest or a belief that the aspirations of the disputing parties are not achieved simultaneously (simultaneously). Dean G Pruit saw disputes over differences in interests or the parties not reaching an agreement [9]. Concerning medical services by nurses to patients, conflicts will arise when the patient's expectations for the process of health / medical services to cure the illness he is suffering from do not materialize. In general, the trigger is when the disappointment of these expectations does not materialize without effective communication, it will give rise to medical disputes.

\subsection{Medical Dispute}

In the world of health, disputes that occur in health services are often known as medical disputes. Medical; adjective meaning; treatment-related; medical [10]. A medical dispute only arises when there is a lawsuit to the hospital, a complaint to the police, or a lawsuit to the court. Medical disputes originate from feelings of dissatisfaction on the part of the patient because of the presence of health workers, such as nurses who do not fulfill the achievements as promised, so that the patient or his family looks for the cause of the dissatisfaction. The cause of the dispute between the doctor and the patient is if the patient is dissatisfied with the nurse in carrying out health services or carrying out medical actions.

Medical disputes between patients or their families and health workers or patients with hospitals/health facilities are usually the result or the result of health services without paying attention or neglecting the process. In fact, in health law, it is recognized that health workers or the implementation of health services when providing services are only responsible for the process or efforts made (inspaning verbintenis) and do not guarantee/guarantee the final result (resultalte verbintenis) [11]. Therefore, before there is a decision from the professional court or the incompatibility of medical logic between a patient and a doctor/hospital, the correct term is a medical dispute, not malpractice. In general, the problem of disputes between patients and nurses in this case usually results in lawsuits for various reasons, such as the nurse in default (broken promise); questionable competence; the behavior of nurses is questioned, both professional behavior and personal behavior and so on.

\subsection{Mediation}

One alternative to dispute resolution is to use mediation by asking a third party to help resolve the dispute. The word "mediation" is means dispute resolution involving a third party as an intermediary, or mediating dispute resolution whose mediator is called a mediator or person who is the mediator [12]. Gary Goodpaster defined mediation as a negotiation process of dispute resolution where outsiders who are impartial and neutral is collaborated with the disputing parties to help them to obtain a satisfactory agreement [13].

In general, mediation can be divided into 2 (two) forms, namely, mediation that is carried out outside the Court (non-litigation) and mediation in court (litigation). First, out-of-court mediation (non-litigation) is a mediation that is carried out outside the Court, or mediation carried out by a mediation institution or center with the help of a certified mediator. The process of implementing mediation outside the Court (non-litigation) is regulated in Article 58 and Article 60 of Law No.48 of 2009 concerning Judicial Powers in Chapter XII concerning Out-of-Court Dispute Resolution.

Second, mediation in court (litigation) is a mediation process that is integrated with court proceedings. The implementation of mediation in the trial process at the First Level Court is a must for the Judge, Mediator, Parties, and/or their Legal Counsels, as regulated in Article 3 
paragraph (1) of the Supreme Court Regulation Number 1 of 2016. In this case, the mediator is not authorized to decide the dispute but only helps the parties to resolve issues that are authorized to him [14].

\subsection{Health Service}

According to Law no. 36 of 2009 , health services consist of individual health services and community health services. The health services referred to include activities with a promotive, preventive, curative, and rehabilitative approach [15]. Individual health services are aimed at curing illnesses and restoring individual and family health. Public health services are aimed at maintaining and improving health and preventing diseases of a group and society. The implementation of such health services must prioritize helping the safety of patients' lives over other interests [16]. Furthermore, in the same law, it is stated that the implementation of health services is carried out in a responsible, safe, quality, equitable and non-discriminatory manner. [17]. One form of health service is nursing service, which is a form of professional service that is an integral part of health services based on nursing knowledge and tips aimed at individuals, families, groups, or communities, both healthy and sick [18].

\subsection{Legal Protection}

Legal protection is the right of every citizen, and on the other hand, legal protection is an obligation for the state itself, therefore the state is obliged to provide legal protection to its citizens, including nursing health workers in carrying out their duties and professions. In principle, legal protection for the community rests on and is rooted in the concept of recognition and protection of dignity as a human being, so that recognition and protection of the rights of suspects are part of human rights without discrimination.

Soerjono Soekanto said that legal protection is all efforts to fulfill rights and provide assistance to provide a sense of security to witnesses and/or victims, which can be realized in forms such as through restitution, compensation, medical services, and legal assistance [19]. Satjipto Raharjo argues that legal protection is to protect human rights (HAM) that are harmed by others and that protection is given to the community so that they can enjoy all the rights provided by law [20]. Because the nature and purpose of the law are to protect the community, which must be realized in the form of legal certainty.

There are two kinds of means of legal protection, namely [21]:

a. Preventive Legal Protection Means. In this preventive legal protection, legal subjects are given the opportunity to submit objections or opinions before a government decision takes a definitive form. The goal is to prevent disputes.

b. Repressive Legal Protection Means. Repressive legal protection aims to resolve disputes. The handling of legal protection by the General Courts and Administrative Courts in Indonesia is included in this category of legal protection. The second principle that underlies the legal protection of governmental acts is the rule of law principle. Concerning the recognition and protection of human rights, recognition and protection of human rights has a central place and can be linked to the objectives of the rule of law.

\section{Methodology}


This research is using normative legal research, which is a research that purposed to examine legal norms or principle [22]. The approach that be used in this research is statute approach and conceptual approach [23].

\section{Result and Discussion}

Philosophically, dispute resolution is an effort to restore the relationship between the parties to the dispute in its original state, by restoring this relationship, they can establish both social and legal relations with one another. One way of resolving disputes in health care or medical disputes is through Alternative Dispute Resolution (ADR). According to Law No. 30 of 1999 concerning Arbitration and Alternative Dispute Resolution, that what is meant by alternative dispute resolution is a dispute resolution institution or difference of opinion through a procedure agreed by the parties, namely settlement outside the court through consultation, negotiation, mediation, conciliation, or expert judgment [24]. However, the definition of each form of APS is not further elaborated in the law.

One form of dispute resolution in this context is through mediation. Settlement through mediation can be carried out by a third party (mediator) both outside the judicial system and within the judicial system. Based on Supreme Court Regulation No. 1 of 2008, the Supreme Court encourages mediation in court to become an obligation for the parties before the examination of medical disputes begins, this is to reduce the buildup of cases in court. Mediation can solve problems quickly, effectively, and efficiently. Furthermore, Supreme Court Regulation No. 1 of 2016 concerning Mediation Procedures in Courts, defines mediation as " $a$ way of resolving disputes through the negotiation process to obtain an agreement between the parties assisted by a mediator".

The use of mediation as a form of legal protection for nurses as health workers is also regulated in Law no. 36 of 2009 concerning Health, Article 29 which states that "If a health worker is suspected of negligence in carrying out his profession, the negligence must be resolved first through mediation". Apart from that, it is also regulated in Law no. 36 of 2014 concerning Health Workers, Article 78 which states that "If health workers are suspected of negligence in carrying out their profession which causes harm to the receipt of health services, disputes arising from negligence must be resolved first through dispute resolution outside the court under the provisions of the legislation".

This provision stipulates that all patient losses caused by health services must be resolved first through out-of-court dispute resolution or APS which is an effort to resolve disputes outside of litigation (non-litigation). It should be noted that nurses are included in the group of health workers [25] as regulated by Law no. 36 of 2014. Dispute resolution through mediation as stated in Law no. 36 of 2014 Article 29 and Law no. 36 of 2014, provides space for nurses to avoid the long and tiring legal process and threatens their profession which is much needed by the community. Mediation is repressive legal protection that can be taken to settle lawsuits. Repressive legal protection through mediation provides benefits to disputing parties.

According to John W Head, mediation is an intermediary procedure in which a person acts as a vehicle to communicate between the parties so that their different views on the dispute can be understood and possibly reconciled, but the main responsibility for achieving a sense of peace remains with the parties themselves [26]. Therefore, it is necessary to seek mediation to reach a peace agreement between the parties. Based on the study of Chris Stern Hyman and Clyde B Schechter, mediation for plaintiffs and defendants is a fair, satisfying, and fulfilling solution. Mediation is based on three main values, namely autonomy, informed consent, and 
confidentiality. Each party can withdraw from the mediation process at any time without binding consequences [27].

Mediation efforts are supposed to be different from litigation efforts in court. One difference is that the mediation effort must be carried out as soon as possible. Mediation has the principle that the results of decisions do not prioritize legal considerations and reasons, but based on equality, appropriateness, and a sense of justice. It should be noted that nurses have tried to provide nursing services to patients under the code of ethics, nursing service standards, professional standards, standard operating procedures, and statutory provisions as stipulated in Law no. 38 of 2014 concerning Nursing Article 37 letter $b$. So, there may be no intention/intention to harm the patient because it involves the professionalism and credibility of the nurse herself.

What happens here is that in practice it is often a fabric of professional ethics, professional discipline, and law problems in general. Coincidentally, whether the patient/community, doctor/hospital is aware of it or not, they often confuse the three. This may be the result of practical ignorance itself or because their way of working wants to be completely practical, and besides, it is not their job to academically sort out whether the case is a violation of pure ethics, professional discipline, administrative law, civil law, or criminal law.

Here the importance of using mediation in dispute resolution as an alternative form of dispute resolution / APS, in this case employing closed mediation between the disputing parties. Through this mediation, it is hoped that the real problems that occur are most likely caused by problems of professional ethics and professional discipline. Through mediation, it is also hoped that good communication will be established so that there is a common ground and mutual understanding will arise which in turn results in a mutual agreement in writing in court or outside the court under the applicable laws.

Based on the description above, that the method of mediation is the right way to resolve disputes between nurses and patients, except in pure criminal proceedings, such as sexual harassment, disclosure of medical secrets, abortion, and gross negligence, false information, fraud, and others. Settlement through litigation will be detrimental to both parties, but it takes a long time and also costs a lot. Another positive effect of the mediation process is that the nurse-patient relationship will always be well preserved. Because after all, both parties need the same interests even in their respective contexts and responsibilities.

\section{Conclusion and Suggestion}

\subsection{Conclusion}

The use of mediation in resolving disputes between nurses and patients in health services is appropriate as a form of legal protection. Mediation is an alternative dispute resolution that is considered practical compared to dispute resolution through litigation or legal processes in court which tend to be long and expensive. By using this method of mediation, it is hoped that there will be a peace agreement that is a win-win solution based on mutual respect, mutual understanding, mutual understanding.

\subsection{Suggestion}

The need for legal protection for nurses in carrying out their duties according to their profession. Nurses in performing their duties are obliged to comply with professional 
standards and respect the rights of patients so that problems do not occur. It is also necessary to establish an Honorary Council for Nursing Discipline Indonesia (MKDPI), such as the MKDKI in medicine as an institution that has the authority to determine whether there are mistakes made by nurses in the application of nursing disciplines and to determine sanctions and have the authority to examine and give decisions on complaints related to discipline. nursing, whose procedures are governed by separate regulations. The importance of the existence of MKDPI is because its opinions and decisions are needed to become material for legal considerations as a form of legal protection for nurses in Indonesia.

\section{References}

[1] Undang-Undang Republik Indonesia Nomor 36 Tahun 2009 tentang Kesehatan.

[2] Undang-Undang Republik Indonesia Nomor 36 Tahun 2014 tentang Tenaga Kesehatan.

[3] Undang-Undang Republik Indonesia Nomor 38 Tahun 2014 tentang Keperawatan.

[4] Doctrine "Res ipsa loquitor", in English "the things speaks for itself.

[5] Undang-Undang Republik Indonesia Nomor 30 Tahun 1999 tentang Arbitrase dan Alternatif Penyelesaian Sengketa.

[6] Novianto, Widodo Tresno.: Sengketa Medik Pergulatan Hukum dalam Menentukan Kelalaian Medik. UNS Press, (2017).

[7] Shofie, Yusuf.: Penyelesaian Sengketa Konsumen Menurut UUPK Teori \& Praktik Penegakkan Hukum. Citra Aditia Bakti, Bandung (2003).

[8] Friedman, L.M.: The Legal System, A Social Science Perspective. New York: Russel Sage Foundation, pp. 225-226 (1975).

[9] Pruit, Dean G dan Jeffrey Z Rubin.: Konflik Sosial. Pustaka Pelajar, Yogyakarta (2004).

[10] Echols, John M. dan Hasan Shadily.: Kamus Inggris -Indonesia. Cet XXIV. Gramedia, Jakarta (1977).

[11] Novianto, Widodo Tresno.: Sengketa Medik Pergulatan Hukum dalam Menentukan Kelalaian Medik. UNS Press, (2017).

[12] Usman, Rachmadi.: Mediasi di Pengadilan (Dalam Teori dan Praktik). Sinar Grafika, pp. 23. Jakarta (2012).

[13] Umam, Khotibul.: Penyelesaian Sengketa Di Luar Pengadilan. Pustaka Yustisia, Yogyakarta (2010).

[14] Umam, Khotibul.: Penyelesaian Sengketa Di Luar Pengadilan. Pustaka Yustisia, Yogyakarta (2010).

[15] Undang-Undang Republik Indonesia Nomor 36 Tahun 2009 tentang Kesehatan.

[16] Undang-Undang Republik Indonesia Nomor 36 Tahun 2009 tentang Kesehatan.

[17] Undang-Undang Republik Indonesia Nomor 36 Tahun 2009 tentang Kesehatan.

[18] Undang-Undang Republik Indonesia Nomor 38 Tahun 2014 tentang Keperawatan.

[19] Soekanto, Soerjono.: Pengantar Penelitian Hukum. UI Press, Jakarta (1984).

[20] Rahardjo, Satijipto.: Ilmu Hukum. PT. Citra Aditya Bakti, Bandung (2000).

[21] Hadjon, Phillipus M.: Perlindungan Hukum Bagi Rakyat Indonesia. PT. Bina Ilmu, Surabaya (1987).

[22] Mertokusumo, Sudikno.: Penemuan Hukum. Cahaya Atma Pustaka, Yogyakarta (2014).

[23] Marzuki, Peter Mahmud.: Penelitian Hukum. Kencana, Jakarta (2008). 
[24] Undang-Undang Republik Indonesia Nomor 30 Tahun 1999 tentang Arbitrase dan Alternatif Penyelesaian Sengketa.

[25] Undang-Undang Republik Indonesia Nomor 36 Tahun 2009 tentang Kesehatan.

[26] John W, Head.: Pengantar Umum Hukum Ekonomi. Proyek ELIPS, Jakarta (1997).

[27] Hyman, Chris Stern, Clyde B. Schechter.: Mediating Medical Malpractice Lawsuits Against Hospitals; New York City's Pilot Project. Health Affairs 25, No.5:1394-1399 (2006). 